\title{
Shakespeare and the Actor's Body
}

\author{
ALEXANDER LEGGATT
}

In his book Shakespeare and the Energies of Drama Michael Goldman declares, 'An actor's profession and desire are to interest people with his body.' "Those of us who believe in the importance of the dramatic text may protest that he's got it wrong, that he really means dancers. But what he is saying, in a deliberately provocative way, is that the total presence of the actor, not just his voice, is the essential starting point of theatre. When in the early days of film D.W. Griffith wanted to use close-ups, his employers discouraged him on the grounds that the public paid to see a whole actor. Their thinking was determined by the stage, and on those terms they had a point; the public does pay to see a whole actor. Shakespeare's public certainly did. ${ }^{2}$ We may suppose that, having no occasion to think about the differences between theatre on the one hand and film, television, radio and recordings on the other, Shakespeare and his contemporaries would not be particularly conscious of this. But it seems that they were. Plays were starting to be printed with some regularity, and this evidently provoked certain writers into thinking about the differences between the text in performance and the text in print; the text with actors and the text without. In his address to the reader prefaced to The Malcontent John Marston declares himself reluctant to wrest the play to a new medium: 'only one thing afflicts me, to think that scenes invented merely to be spoken should be enforcively published to be read' and adds a hope "that the unhandsome shape which this trifle in reading presents may be pardoned, for the pleasure it once afforded you when it was presented with the soul of lively action. ${ }^{3}$ More briefly, his preface to The Fawn declares, "the life of these things consists in action.'4 Ben Jonson, on the other hand, increasingly distrusted the theatre and used the reader as a final court of appeal when the audience had failed him. He too imagines a split between the text itself and the text in performance, and for him, characteristically, this is a split between what is heard and what is seen. In the Prologue for the Stage that opens The Staple of News he has an actor declare: 
For your own sakes, not his, he bade me say Would you were come to hear, not see a play Though we his actors, must provide for those Who are our guests, here, in the way of shows, The maker hath not so; he'd have you wise, Much rather by your ears, than by your eyes. ${ }^{5}$

It is equally characteristic of Shakespeare not to make pronouncements of this kind. But his awareness of the issue is suggested by a passage in Coriolanus in which Volumnia advises her son on the way to court the people:

Go to them, with this bonnet in thy hand, And thus far having stretch'd it - here be with them -

Thy knee bussing the stones; for in such business

Action is eloquence and the eyes of th'ignorant

More learned than the ears ...

(III.ii.75-9) $)^{6}$

We have our usual difficulty here; we cannot disentangle the speech from its dramatic situation to get from it a statement by Shakespeare about his own art. If anything, it seems to express a Jonsonian contempt for the vulgar who need something to look at. Against it we may set Henry V's instructions to his soldiers before Harfleur, which are like instructions to an actor on how to strike the right stance for the role of the warrior:

\footnotetext{
Stiffen the sinews, summon up the blood,

Disguise fair nature with hard-favor'd rage.

Then lend the eye a terrible aspect:

Let it pry though the portage of the head

Like the brass cannon; let the brow o'erwhelm it

As fearfully as doth a galled rock

O'erhang and jutty his confounded base,

Swill'd with the wild and wasteful ocean.

Now set the teeth and stretch the nostril wide,

Hold hard the breath, and bend up every spirit

To his full height.
}

At the end of the speech Henry survey his troops and decides they look right: 'I see you stand like greyhounds in the slips, / Straining upon the start' (31-2). Only then are they asked to cry, 'God for Harry, England, and Saint George'(34).

A foreign visitor to England at this time noted that actors 'are daily instructed, as it were in a school, so that even the most eminent actors have to allow themselves to be taught their places by the dramatists. " I 
have never been quite sure how to take this, but it suggests that besides his work as an actor and playwright Shakespeare may have had some experience as a director. Behind the speeches of Volumnia and Henry V, determined though they are by character and situation, may be Shakespeare's awareness of the physical side of the actor's art: the importance of significant gesture, certainly; and perhaps in Henry's speech an idea that is basic to the training of actors in our own time, the importance of physical preparation to get the voice right. An actor who is not standing properly will not speak properly. Whether Shakespeare thought in those terms or not, he does not seem to have had Jonson's desire to separate the word from the rest of the theatrical experience. For him the verbal and physical work together. The actor is a total presence, not just a voice; and he does, as Michael Goldman suggests, interest us with his body.

At the most obvious level Shakespeare gives his heroes the chance to demonstrate their heroism physically. An actor preparing the role of Hamlet can read as much or as little philosophy as he likes, but if he doesn't brush up his fencing he's in trouble. Coriolanus' heroism, and his obsessive relationship with Aufidius, are not just talked about but shown in hand-to-hand combat. Macbeth's deepest humiliation is his refusal to continue the fight with Macduff; the final rescue of his dignity comes when he picks up his sword and shield and carries on. In both cases his action is more eloquent than his language. Romeo, unlike Tybalt or Mercutio, talks very little about fighting; it is love that commands his language, and he fights only under compulsion. But he fights twice and kills his man both times. If we are tempted to think of Romeo as a nice young man in love, we have to remember that he is also, when cornered, a dangerous man. So is Richard II, whose decision to go down fighting is an explosive surprise at the end of a relatively static play.

In each case the physical action tells us something - and occasionally something unexpected-about the character. It is also a way of releasing dramatic tension. Richard II begins with elaborate preparations for a trial by combat that never takes place; armies march back and forth across the stage but never strike a blow. When Richard at last decides to make a fight of it, the effect is both a surprise and a physical relief. Sometimes a play will build towards a scène à faire which turns out to be a combat. The last two acts of Richard III build slowly but steadily to a showdown between Richard and Richmond; when they meet they exchange no words; it is all done through fighting. Henry IV Part One builds to a similar confrontation between $\mathrm{Hal}$ and Hotspur. Hal describes himself as 'the Prince of Wales ... / Who never promiseth but he means to pay' (V.iv.42-3). In the combat with Hotspur he keeps his promises to his father, to his rival, and to the audience. But this time Shakespeare complicates the effect. While Hal is fighting Hotspur, 
Falstaff is fighting Douglas, in what is presumably a comic sideshow to the main event. This pulls the focus away from Hal, and anticipates the realization that his defeat of Hotspur is not, and could not have been, the full climax to his career. The ironies continue as the man of fiery spiritHotspur - dies in a final, blank despair and the man of flesh - Falstaff miraculously returns from apparent death. His gross, disreputable body rises from the ground, indestructible. But Hotspur just lies there, his helplessness dramatized in the grotesque moment when Falstaff stabs him in the thigh.

In Henry IV Part One, then, the heroic is both asserted and sabotaged in physical terms. In Troilus and Cressida the effect of the combat as dramatic climax is subject to twofold parody. All through the play we are built up to the moment when Achilles emerges from his tent to fight Hector. Hector's position as the life and soul of Troy and the anxiety of the Greeks to bring Achilles into the war lead us to expect something spectacular. What we get instead is a feeble combat between two men who are out of condition, one because he has already put in a long day on the battlefield, the other because he has neglected his training. At Hector's suggestion they simply call it off, and Achilles later sets his Myrmidons to work. In some productions Achilles leaves killing entirely to them, and does not strike a blow himself; ${ }^{8}$ this staging is justified by the text. Shakespeare builds on this moment for the death of Coriolanus. We have heard - and seen with our own eyes - that Aufidus can never defeat his rival in single combat. And so, like Achilles, he sets on him with a gang. ${ }^{9}$ The conspirators kill Coriolanus and Aufidius 'stands on him' (V.vii.135). The hero's body has been the focus of attention even in the political scenes of the play; he is asked not just to speak to the people but to show them his wounds. Here that body is subjected to a final insult. But Aufidius is more deeply degraded by the action than he is.

What we may call the athletic side of the Shakespearean hero has been frequently remarked on, though we do not always notice how full and complex the physical language can be. But it is, or used to be, a commonplace to observe that Shakespeare's lovers do it with words alone. In a theatre that used boy actors, so the argument runs, there could be no physical suggestion of the erotic, and so the love-making is done through poetry. This argument does great credit to the purity of mind of those who have advanced it. But the fact is that Shakespeare's lovers, no less than his fighters, have bodies. Orlando is as it were a transitional figure. Though the dialogue does not require much physical contact between Orlando and Rosalind, a number of devices call attention to his body. When Rosalind first sees him he is winning a wrestling match, and her reaction is ' $\mathrm{Sir}$, you have wrestled well and overthrown/ More than your enemies' (I.ii.244-5). He continues to express his virtue in physical 
terms; we hear of his courage in tackling the lioness, and (more important for the present argument) we see his gentleness and piety when he carries Old Adam. And though Rosalind's love for him has many aspects, her language makes it clear that the practical, physical side is never far from her mind. It is his poetry she does not think much of.

It takes a modern film director to follow Romeo and Juliet into the bedroom; but even for Shakespeare their love is not just verbal. Their first dialogue, at the Capulets' ball, is accompanied by a formal touching of hands and by two kisses. The first concludes the argument of a clever sonnet they have shared; the second concludes an extra quatrain they have added by way of indicating that fourteen lines are not enough. In their most famous scene together they are, we might say, not together at all, but separated by the physical barrier imposed by Juliet's balcony. As they speak across the barrier, we become aware of other forces that are keeping them apart. When in a later scene they appear on the balcony together we know at once that they have made love. The effect is at once simple and more powerful than anything a camera in the bedroom could show. When Romeo descends, the balcony becomes again a barrier. In their last scene together each one kisses the other's unresponding lips; and the final sight of them lying together in the tomb is the closest approximation we have to the sight of them in bed. It fulfills Romeo's promise, 'Well, Juliet, I will lie with thee tonight' (V.i.34) and concludes the paradoxical interplay of sex and death that has run through their language. We can trace their relationship, in other words, through what we see, and this side of the play is more fully developed than the traditional concentration on the language might allow.

The stage gallery is used again to very different effect in Antony and Cleopatra to express the nature of a more sophisticated and ironic love affair. Antony, who has just blown his first death scene, is hauled up to Cleopatra's monument to die in her arms. In part the effect confirms a romantic reading of the play: Antony is to die as Cleopatra's lover, not as a Roman soldier; and at this point the two lovers are physically exalted over the Romans. But there is something frantic in the repeated kissing implied in the dialogue. The kisses of Romeo and Juliet are carefully rationed, and each one is telling. This is appropriate for two lovers who have only one night together. Antony and Cleopatra, we feel, lost count long ago. And there is an important visual irony in the difficult business of hauling Antony up to the monument. If a recent suggestion by Margaret Lamb is correct, the rewritten version of Samuel Daniel's Cleopatra may report a piece of stage business from the King's Men's production: Antony gets stuck half-way up and dangles in mid-air, dripping blood on the spectators below. ${ }^{10}$ It sounds grotesque; but it may be that the best way to handle the physical difficulty of the scene is not to 
evade it by stylization, as Peter Brook and other directors have done, but to emphasize it. (Anyone who has seen a mediaeval crucifixion play well performed knows that the sheer physical difficulty in raising the cross is a powerful dramatic effect.) Even without the details reported by Daniel, there is something undignified about what is happening to Antony; it confirms an earlier image of their love. Cleopatra, killing time during Antony's absence, decides to go fishing:

\section{I will betray}

Tawny-finn'd fishes. My bended hook shall pierce

Their slimy jaws, and, as I draw them up,

I'll think them every one an Antony;

And say, 'Ah, ha! Y'are caught.'

$$
\text { (II.v.11-5) }
$$

Cleopatra is landing her fish. In a physical effect that corresponds to the paradoxical quality of the play's language, Antony's body is simultaneously exalted and degraded. The effect confirms our double vision of Antony as both a demigod whose legs bestride the ocean and a strumpet's fool.

Cleopatra prepares for her own death scene by declaring, 'I am fire and air; my other elements / I give to baser life' (V.ii.289-90). But in fact her death scene is full of physical detail, of touching and handling. Her attendants put her robe and crown on her, she kisses them, she applies the asp to her body, and after she dies Charmian straightens her crown. She not only describes the asp as the baby at her breast, she encourages it as she might encourage a clumsy lover: 'Poor venomous fool, / Be angry, and despatch' (V.ii.305-6). We might notice that though directors usualy put her on a throne the text specifies a bed. In Cleopatra's death scene, as she would like to see it, the gypsy strumpet is burned away and we are left with the tragedy queen. But the physical quality of the scene suggests that we have here not a born-again Cleopatra but the Cleopatra we have always known. The heroic, the erotic and the ironic qualifications to which both are subject, have their physical expression on Shakespeare's stage. 'Love's mysteries in souls do grow, / But yet the body is his book.' "1 That was how Donne put it. But the body also lets us down. Ben Jonson complained that the power of his love poetry could not survive the sight of 'my mountain belly, and my rocky face. ${ }^{12}$ So Achilles seems a formidable warrior till we actually see how out of shape he is; and Cleopatra sabotages her own performance as a tragedy queen by her inability to keep her hands still.

There are certain plays of Shakespeare in which this concern for the physical comes into particularly sharp focus, and becomes fundamental to the play's argument. I would now like to look at some of these in turn. 
On the face of it, any discussion of Shakespeare and the body should include what happens to Lavinia in Titus Andronicus. Nowhere in Shakespeare, we may think, is the integrity of a human body so spectacularly violated as in the entrace of Lavinia 'her hands cut off, and her tongue cut out, and ravish'd' (II.iv.1). But the dialogue that follows - the brutal wit of Chiron and Demetrius, the Ovidian decorations of Marcusis so stylized, so consciously literary, that our attention seems directed not to what has happened to Lavinia's body but to what can be said about it. It is in a later scene that the full significance of the mutilation is brought home to us as Lavinia, in order to write a message to her family, has to sit on the ground, take a staff in her mouth, and guide it with her feet and her stumps. The grotesque difficulty of performing an act that is normally so easy dramatizes how far Lavinia has been robbed of her ordinary humanity. The violation of the body continues throughout the play, of course: a severed hand, a number of severed heads, and a cannibalistic banquet. In no other tragedy of Shakespeare's is the tangle of human cruelty and suffering expressed in so physical a way. And yet the most disturbing effect, I think, is the skirmish after the banquet in which three people are killed in four lines, one of them the nominal hero of the play. The author of The Revenger's Tragedy will do something like this as part of his black-comic vision of the world; but he does it only to his minor characters, and allows Vindice a grand last speech before he is marched off. Shakespeare denies this to Titus. He has no last speech; there is no particular focus on his death. What began as a tragic action has become a fast, mechanical killing machine and Titus is just one corpse in a pile of corpses.

But Titus's dignity is restored after his death, in a ceremony as formal as many of the play's cruelties have been. Lucius commands,

LUCIUS: Stand all aloof, but, uncle, draw you near

To shed obsequious tears upon this trunk.

$\mathrm{O}$, take this warm kiss on thy pale cold lips,

These sorrowful drops upon thy blood-stain'd face,

The last true duties of thy noble son!

MARCUS: Tear for tear, and loving kiss for kiss,

Thy brother Marcus tenders on thy lips.

$O$, were the sum of these that I should pay

Countless and infinite, yet would I pay them!

LUCIUS: Come hither, boy. Come, come, and learn of us

To melt in showers. Thy grandsire love'd thee well.

Many a time he danc'd thee on his knee,

Sung thee asleep, his loving breast thy pillow;

Many a story hath he told to thee,

And bid thee bear his pretty tales in mind,

And talk of them when he was dead and gone. 
MARCUS: How many thousand times hath these poor lips, When they were living, warm'd themselves on thine!

Oh now, sweet boy, give them their latest kiss.

Bid him farewell; commit him to the grave;

Do them that kindness and take leave of them.

(V.iii.151-71)

The mutilated body of the hero is formally honoured by the kisses of his brother, son and grandson. Decency, piety and family affection are evoked as part of the general restoration of humane values at the play's ending. The scene is as slow and deliberate as the killings were frantic. It is crudely done, perhaps; but it restores through physical gesture some of the dignity and integrity that Titus had lost in the course of the action.

What is crudely done in Titus is done more boldly and finely in King Lear. The importance of the visual in this play has been much discussed, and I need only remind you of a few key moments. The play deals in shocking collisions between word and picture. Edgar has just arrived at an acceptance of his fate on the grounds that he is at the bottom and has no farther to fall, when Gloster enters blind and led by an old man. Edgar, again, has just led his father to 'Bear free and patient thoughts' (IV.vi.80) when Lear enters mad and crowned with flowers. Albany cries, 'The gods defend her!' (V.iii.260) and Lear enters with Cordelia dead in his arms. Far from being unstageable, the play is as essentially theatrical as anything Shakespare wrote. The sheer presence of the actors, and even of the stage itself, carries much of the argument. In the Dover Cliff sequence the theatrical game of make-believe is deliberately reversed; we are asked not to forget but to remember that we are in the Globe theatre and the stage is flat. The blinding of Gloster is a physical violation more horrible than anything in Titus, and with deeper meaning. More complex is the figure of Poor Tom. This time the human body is not violated but simply exposed, revealed to Lear as that of 'a poor, bare, forked animal' (III.iv.106). Lear takes this as a final, irreducible truth about humanity: 'Thou art the thing itself' (105). But we cannot settle in this view. Poor Tom is also a put-on, a disguise adopted by Edgar who has, paradoxically, concealed himself by taking his clothes off. This may provoke us to thinking that man in his natural state is not naked but clothed, whatever Lear may claim to the contrary. Moreover Poor Tom, the vehicle for some of the play's darkest insights, is a creation of Edgar, its chief spokesman for reason and hope. And Edgar has his own interpretation of Tom, which is different from Lear's. For him the poor bare forked animal is a wicked animal: 'hog in sloth, fox in stealth, wolf in greediness, a dog in madness, lion in prey' (III.iv.92-3). Edgar, typically, moralizes Tom as Lear does not. The naked madman is not a secure 
truth; it is an image to be argued about. The exact effect of the body in question will depend on the casting of Edgar, but it is presumably a mistake to aim for the athletic or the erotic. An Elizabethan actor, stripped to a blanket in a roofless theatre in England, would have looked, above all, vulnerable. Edgar is one of the play's exemplars of virtue, and its principal survivor. When he leads his blind father by the hand, he expresses his kindness in physical terms, as Orlando did with Old Adam. When he kills Oswald and then Edmund in single combat he becomes one of Shakespeare's athletes of virtue. But when we see him dressed as a peasant or armed as a knight we can never quite forget the naked madman of the storm scenes, whose frailty works against everything Edgar consciously stands for. The actor's body is constantly resisting his words.

The same thing happens in a more terrible way with Cordelia. Much of the language associated with her suggests a spiritual power of healing and restoration. Her words, ' $\mathrm{O}$ dear father, / It is thy business that I go about' (IV.iv.23-4) bring a Christian colouring to this pre-Christian story; so does the language of her reunion with Lear. But if we are tempted to see Cordelia as a Christ-figure this only emphasizes the decisive and terrible difference at the end, when the resurrection Lear so desperately looks for does not happen. In the later scenes Lear, who has been much concerned with humanity in general, with justice and love, with suffering and cruelty, totally loses his interest in such abstractions and focuses his mind on one thing: Cordelia. And the final fact about Cordelia is that she is dead. As in Titus, there is a close concentration on a dead body. When we think of the relative achievement of the two scenes it seems absurd to mention them together, but in this as in much else Titus has prepared the ground for Lear. There is a formal return to the play's opening as Lear pleads with Cordelia to speak and she remains silent. There is a fundamental image of human love, a father cradling a child. Above all there is a close concentration on the physical, Lear's body as well as Cordelia's:

Pray you, undo this button. Thank you, sir.

Do you see this? Look on her, look, her lips,

Look there, look there!

$(\text { V.iii.314-6) })^{13}$

Cordelia has stood for salvation and restoration, for everything that wicked and suffering humanity can hope for. But as Edgar's naked body makes a statement that works against the character's beliefs, so the dead body of Cordelia makes a final statement that works, terribly, against everything the character has made us hope for.

Shakespeare's interest in parents and children is given a radically 
different twist in Coriolanus. The play is full of fighting, but also full of embraces; and I have noted the way we are asked to concentrate on the hero's body even in the political scenes. The importance of the body in the play's language, beginning with Menenius' fable, has frequently been noted. The embraces of the battlefield are talked about, interpreted in words. Marcius greets Cominius:

\section{$\mathrm{O}$, let me clip ye}

In arms as sound as when I woo'd, in heart As merry as when our nuptial day was done, And tapers burnt to bedward!

$$
\text { (I.vi.29-32) }
$$

Aufidus later greets his old rival in similar terms:

Let me twine

Mine arms about that body, whereagainst

My grained ash an hundred times hath broke, And scarr'd the moon with splinters. Here I clip

The anvil of my sword, and do contest

As hotly and as nobly with thy love

As ever in ambitious strength I did

Contend against thy valor. Know thou first,

I lov'd the maid I married; never man

Sigh'd truer breath. But that I see thee here,

Thou noble thing, more dances my rapt heart

Than when I first my wedded mistress saw

Bestride by threshold.

(IV.v.111-23)

We do not have to speculate here on the relationship between the excitement of battlefield and the excitement of sexual love; criticism has not been silent on the subject. It is enough to note that the relationship exists, that the soldiers cannot embrace each other without thinking of their wives. Later, Coriolanus cannot embrace his wife without thinking of the war he is engaged in: ' $\mathrm{O}$, a kiss / Long as my exile, sweet as my revenge!' (V.iii.44-5). Technically Coriolanus is both a very physical play and an extremely verbose one; it also has a special interest in man as a social animal. It is appropriate, therefore, that the embraces are accompanied by speeches of interpretation that see one set of relationships in terms of another.

When Coriolanus yields to his mother the stage direction 'holds her by the hand, silent' (V.iii.182) may suggest that for once no words are adequate. We focus on the first of relationships, mother and child. But after the silence comes, again, a speech of interpretation; only this time the gesture's meaning is extended into a dreadful irony: 
O mother, mother!

What have you done? Behold, the heavens do ope,

The gods look down, and this unnatural scene

They laugh at.

(V.iv.183-6)

What looked at first like a moment of humanity and love is also a moment in which a mother sends her son to his death. The gesture, we now realize, conveys something of that as well. For Coriolanus to take Volumnia by the hand implies something less than a full embrace. There is in the gesture not just acceptance but a certain wariness. Coriolanus both takes his mother by the hand and keeps her at arm's length.

In the final romances, as we might expect, Shakespeare's concern with human ties shows itself in significant embraces. But there are also two striking gestures of rejection, which we might pause over. When Marina comes to Pericles on his barge his first reaction is to say, 'Hum, ha!' and push her away (V.i.86). Like Lear in his parallel scene with Cordelia, he cannot at first cope with comfort. The gesture of rejection is for the most part a sign of the Timon-like inhumanity to which Pericles has descended in his grief. But it is also a preparation for the reunion that is to come. So is the equivalent moment in the finale of Cymbeline. One cause of the play's diffuseness is that the outrage Posthumus has done to Imogen is done at long range, through letters and messengers. In this phase of their relationship they do not confront each other directly. In the last scene the repentant Posthumus encounters Imogen in disguise, thinks she is mocking him, cries, 'Shall's have a play of this? Thou scornful page, / There lie thy part' (V.v.230-1), and flings her to the ground. Her later question, 'Why did you throw your wedded lady from you?' (V.v.263) may apply not just to this moment but to the whole course of their love, and Posthumus' theatrical language suggests that this brief action is a reenactment in little of the main play. With the theatrical self-consciousness characteristic of Cymbaline, we are led to the final embrace of the lovers by a pantomime re-enactment of their earlier conflict.

In both cases the inital, violent rejection sharpens the dramatic effect of the embrace that is to come. There is a swift movement of action and reaction. In the last scenes of The Winter's Tale and The Tempest, on the other hand, there are embraces that have been prepared for through the whole length of the play. In the last scene of The Winter's Tale Hermione appears at first as a statue, still and silent; even her wrinkles are attributable to the new fashion for realism in art. Then the work of art becomes a living woman. Her living body, like the dead body of Cordelia, makes a statement of its own. It resolves the play's running debate between art and nature, being simultaneously a miraculous work of art and ordinary 
flesh and blood. Time seems defeated by her return from death; but the miracle happens under conditions imposed by time. She is so much the focus of attention in this scene, and says so much by simply being there, that it is hard to remember she has only one speech, greeting and blessing her daughter. This is the only relationship she acknowledges in words. She says everything else, like Coriolanus or Cordelia, in silence. Her silence, unlike that of Isabella at the end of Measure for Measure, does not leave the performer's options open. She embraces Leontes, and 'hangs about his neck (V.iii.113) before she says a word to any one. In his jealousy he calls to her 'Too hot, too hot!'(I.ii.108). Those words convey the disgust with the body - 'paddling palms and pinching fingers' (I.ii.115) - that runs through his early speeches. His first words as she embraces him are 'O, she's warm!' (V.iii.109). We not only see the embrace, we sense what it feels like. Leontes is rejoicing not only in Hermione but in the simple physical pleasure of the body as an instrument of affection. His earlier speeches conveyed a queasy disgust with the physi$\mathrm{cal}$; this sickness is now purged. And his simple joy in the fact that Hermione is warm may suggest one reason why the play is called The Winter's Tale.

The embrace that marks the return of common humanity at the end of The Tempest is between Prospero and Alonso:

Behold, sir King,

The wronged Duke of Milan, Prospero.

For more assurance that a living prince

Does now speak to thee, I embraced thy body;

And to thee and thy company I bid

A hearty welcome.

ALONSO:

Whe'er thou b'est he or no,

Or some enchanted trifle to abuse me,

As late I have been, I not know. Thy pulse

Beats as of flesh and blood; and, since I saw thee,

Th'affliction of my mind amends, with which,

I fear, a madness held me.

(V.i.106-16)

The spell breaks and the light of common day returns, not just through Prospero's appearance in ordinary dress, or his naming of himself, but through the touch of his body. As Leontes focussed on the warmth of Hermione, Alonso focusses on the pulse-beat. This picks up a motif we have heard earlier in the language of this closely-woven play. Miranda asks her father why he has raised the storm, 'For still 'tis beating in my mind' (I.ii.176). Her three key words are picked up by Prospero when after the breakup of the wedding vision he asks leave to walk by himself 
'To still my beating mind' (IV.i.163). The embrace of Alonso and Prospero is a restoration of human ties, as in all the final romances; it is also, as in The Winter's Tale, a restoration of the normal. It is, like the embrace of Leontes and Hermione, felt as well as seen. But what is implied in Alonso's observation, 'Thy pulse / Beats as of flesh and blood' is both more particular and more mysterious than Leontes' recognition of the warmth of Hermione. The body is not an inert thing; it has, like the sea, a rhythm. And its rhythm is in some way connected with the rhythms of the mind, which in this play beats with excitement like the heart.

You will have noticed that in the last two cases in particular I have called the play's words to my aid to suggest the larger meaning of the physical gestures. And in one way or another I have been doing so all along. We come back, always, to the text. But as I have tried to show, the text contains clear signals for significant action; and I have tried to suggest beyond this that Shakespeare was concerned with the meaning of the body itself and used his actors' bodies as an important part of the play's theatrical language. Through this medium he shows us what we are heroic, desirable, gross, mortal, miraculous - or simply warm. If Shakespeare's audiences did indeed pay to see a whole actor, he saw to it that they got their money's worth.

\section{University of Toronto}

\section{Notes}

1 (Princeton, 1972), p. 4.

2 Prof. Philip Sohm has pointed out an analogy in the relations of Renaissance painters and their employers; the fee could depend on how many figures were represented and how much of the body was shown.

3 ed. M.L. Wine (Lincoln, 1964), pp. 4-5.

4 ed. Gerald A. Smith (Lincoln: University of Nebraska Press, 1965), p. 5.

5 Ben Jonson, ed. C.H. Herford and Percy and Evelyn Simpson, VI (Oxford, 1938), 282. The spelling of the passage has been modernized.

6 All references to Shakespeare are to the text in The Complete Works of Shakespeare, ed. David Bevington (Glenview, 1980).

7 Johannes Rhenamus, preface to Speculum Aestheticum, quoted from David Klein, 'Did Shakespeare Produce his Own Plays?', Modern Language Review, 57 (1962), 556. The translation is Klein's.

8 This was the case in the recent BBC television production.

9 The Folio seems uncertain as to whether there are two, three or four conspirators; this presumably reflects Shakespeare's uncertainty about the number of actors available at this point.

10 Margaret Lamb, Antony and Cleopatra on the English Stage (London and Toronto, 1980), pp. 180-5.

11 'The Ecstasy,' lines 71-2.

12 'My Picture Left in Scotland,' line 17.

13 The last two lines are not in the Quarto, and were added in the Folio version of the text. 
